\title{
Biophysical suitability, economic pressure and land-cover change: a global probabilistic approach and insights for REDD+
}

\author{
Bernardo B. N. Strassburg • Agnieszka E. Latawiec • Anna Creed • Nga Nguyen • \\ Gilla Sunnenberg • Lera Miles • Andrew Lovett - Lucas Joppa · Ralph Ashton • \\ Jörn P. W. Scharlemann · Felipe Cronenberger · Alvaro Iribarrem
}

Received: 4 October 2012/ Accepted: 3 April 2013/Published online: 3 May 2013

(C) The Author(s) 2013. This article is published with open access at Springerlink.com

\begin{abstract}
There has been a concerted effort by the international scientific community to understand the multiple causes and patterns of land-cover change to support sustainable land management. Here, we examined biophysical suitability, and a novel integrated index of "Economic Pressure on Land" (EPL) to explain land cover in the year 2000, and estimated the likelihood of future land-cover change through 2050, including protected area effectiveness. Biophysical suitability and EPL explained almost half of the global pattern of land cover $\left(R^{2}=0.45\right)$, increasing to almost two-thirds in areas where a long-term equilibrium is likely to have been reached (e.g. $R^{2}=0.64$ in Europe). We identify a high likelihood of future landcover change in vast areas with relatively lower current and past deforestation (e.g. the Congo Basin). Further, we
\end{abstract}

Handled by Osamu Saito, UNU-Institute for Sustainability and Peace (ISP), Japan.

B. B. N. Strassburg and A. E. Latawiec contributed equally to this article.

B. B. N. Strassburg $(\bowtie) \cdot$ A. E. Latawiec

International Institute for Sustainability, Estrada Dona Castorina,

124, Rio de Janeiro 22460-320, Brazil

e-mail: b.strassburg@iis-rio.org

B. B. N. Strassburg

Department of Geography and the Environment, Pontificia

Universidade Catolica, Rio de Janeiro 22453-900, Brazil

B. B. N. Strassburg · A. Creed · R. Ashton

Terrestrial Carbon Group, 900 17th St NW Suite,

Washington, DC 700, USA

A. E. Latawiec

Department of Production Engineering and Logistics, Opole

University of Technology, Luboszycka 5, 45-036 Opole, Poland simulated emissions arising from a "business as usual" and two reducing emissions from deforestation and forest degradation (REDD) scenarios by incorporating data on biomass carbon. As our model incorporates all biome types, it highlights a crucial aspect of the ongoing REDD + debate: if restricted to forests, "cross-biome leakage" would severely reduce REDD + effectiveness for climate change mitigation. If forests were protected from deforestation yet without measures to tackle the drivers of land-cover change, REDD + would only reduce $30 \%$ of total emissions from land-cover change. Fifty-five percent of emissions reductions from forests would be compensated by increased emissions in other biomes. These results suggest that, although REDD + remains a very promising mitigation tool, implementation of complementary measures to reduce land demand is necessary to prevent this leakage.

Keywords Land-cover change - Modelling · Deforestation $\cdot$ REDD $+\cdot$ Climate change $\cdot$ Agriculture expansion

A. E. Latawiec - G. Sunnenberg - A. Lovett

School of Environmental Science, University of East Anglia,

Norwich NR4 7TJ, UK

N. Nguyen

Central European University, Nador u. 9,

Budapest 1051, Hungary

L. Miles · J. P. W. Scharlemann

United Nations Environment Programme World Conservation

Monitoring Centre, 219 Huntingdon Road, Cambridge CB3

ODL, UK

L. Joppa

Microsoft Research, 21 Station Road, Cambridge CB1 2FB, UK 


\section{Introduction}

A better understanding of land-cover change and its impacts on soil degradation (Trimble and Crosson 2000), biodiversity loss (Baillie et al. 2004; IUCN Red List of Threatened Species Version 2011), climate change and food security (Intergovermental Panel on Climate Change 2007), among other global and local effects (Foley et al. 2005) has been perceived paramount for sustainable land management by both researchers and decision-makers (Verburg et al. 2004; Turner 2010). The linkages between land-cover change and policies are bidirectional, with landcover change affecting, and being affected by, decisions such as infrastructure expansion, taxes, tariffs, and subsidies, and the creation of protected areas (PAs) (Reid et al. 2008). The desire to better describe drivers and patterns of land-cover change resulted in the development of several computational models representing a variety of approaches and underlying concepts (Rindfuss et al. 2004; Verburg et al. 2006; Smith et al. 2010). Briefly, among a multitude of classifications, models can be divided into spatial (Pontius et al. 2001; Verburg et al. 2002; Goldstein et al. 2004; Lepers et al. 2005; Bouwman et al. 2006) and nonspatial (Evans et al. 2001; Stephenne and Lambin 2001; Tilman et al. 2001; Ewers 2006), dynamic (GEOMOD; CLUE; SLEUTH) and static (Chomitz and Thomas 2003; Overmars and Verburg 2005), descriptive (Verburg et al. 2006) and prescriptive (Lambin et al. 2000; van Ittersum et al. 2004), global (Rosegrant et al. 2002; Hsin et al. 2004; Lepers et al. 2005; van Velthuizen et al. 2007) and regional (Soares et al. 2006). There is no single superior approach to model land-cover change (Verburg et al. 2006), as no single model is capable of answering all questions and the choice of approach depends on the research or policy questions and data availability.

Among causes of land-cover change, agriculture has historically been the greatest force of land transformation (Ramankutty et al. 2007; Foley et al. 2011), with population growth and per capita consumption driving global environmental change (Tilman et al. 2001). For instance,

J. P. W. Scharlemann

School of Life Sciences, University of Sussex, Falmer,

Brighton BN1 9QG, UK

F. Cronenberger

Deparment of Geography, Universidade Federal Fluminense, Niteroi 24220-900, Brazil

\section{A. Iribarrem \\ Valongo Observatory, Federal University of Rio de Janeiro, Ladeira Pedro Antônio, Rio de Janeiro 20080-090, Brazil}

\section{A. Iribarrem}

European Southern Observatory, Karl-Schwartzschild-Str. 2, Garching bei München, Germany historical datasets reveal that cropland area expanded from 3-4 million $\mathrm{km}^{2}$ in 1700 to $15-18$ million $\mathrm{km}^{2}$ in 1990 , mostly at the expense of forests (Goldewijk and Ramankutty 2004). Gibbs et al. (2010) showed that tropical forests were primary sources of new agricultural land in the 1980s and 1990s. Throughout the tropics, between 1980 and 2000 more than $80 \%$ of new agricultural land came at the expense of intact and disturbed forests (Gibbs et al. 2010). Other studies (Rudel et al. 2005; Ewers 2006) highlighted a strong interaction between land cover and economic development. The notion that the economic pressure for land conversion radiates in concentric circles from markets and diminishes in an inverse relation to distance, dates from the dawn of economic theory (von Thunen 1826). Traditionally, this pressure related to the demand arising from each population centre. Currently, economic globalisation facilitates displacement of agricultural and forestry demands over longer distances and the world economy has experienced an increasing separation between the locations of production and consumption (Lambin and Meyfroidt 2011). For example, in their analysis, DeFries et al. (2010) showed that the traditional mode of clearing in frontier landscapes for small-scale production to support subsistence needs or local markets is no longer the dominant driver of deforestation in many places. Rather, their results indicated that higher rates of forest loss for 2000-2005 were associated strongly with demands for agricultural products in distant urban and international locations (DeFries et al. 2010). Similarly, in their analysis of 12 countries, Meyfroidt et al. (2010) concluded that with the increasing globalisation of trade, there is a displacement of national demands for agricultural lands to other, mainly tropical, countries.

Here, we aim to test the influence of both economic factors, such as calorific demand per capita, demographic data (population size) and biophysical suitability on converted land globally. First, we introduce a novel approach that synthesizes these various variables in order to test their explanatory power in relation to global patterns of land cover. Second, we applied a static modelling approach to combine these variables with spatially explicit information on PAs (and their effectiveness in limiting land-cover change) and we used projected economic and demographic data, in order to predict changes in land cover through to 2050. Third, we produced a map of the likelihood of future land-cover change in United Nations Framework Convention on Climate Change (UNFCCC) non-Annex I countries (mostly developing countries) until 2050. Finally, we illustrate the potential applications of these approaches by combining land-cover change scenarios and a terrestrial carbon map to estimate the impact of a proposed reducing emissions from deforestation and forest degradation (REDD) scheme (UNFCCC 2010; Strassburg et al. 2009). 
REDD activities are amongst those encouraged under the UNFCCC's REDD+ initiative, which seeks to offer financial incentives to developing countries both to reduce greenhouse gases emissions associated with deforestation, and promote the sustainable management of forests, conservation and enhancement of forest carbon stocks.

Our analysis does not seek to estimate short-term changes or to describe the dynamics of land-cover change over time. Thus, whereas models based on short-term relationships can offer useful insights about the near future, our approach complements previous analyses by offering a long-term perspective of possible future land-cover change patterns until 2050. Results of such analyses can be important for long-term sustainability challenges, such as climate change mitigation and biodiversity conservation. Further, our results can be used for a variety of analyses related to land-cover change and sustainability science, also based on spatially explicit data.

\section{Methods}

All spatial data were converted to and analysed at a $10^{\prime} \times 10^{\prime}$ grid using an equal-area Behrmann projection, equivalent to a grid cell of approximately $16 \times 16 \mathrm{~km}$ at the equator. This resulted in approximately 562,000 cells, covering all land surface of the planet.

Our results are presented globally as well as regionally (e.g. for Europe, Latin America or developed and developing countries). Future likelihood of land-cover change is presented for non-Annex I countries of the UNFCCC only. It was assumed that historical drivers of land-cover change may not continue to be major drivers in developed countries (see also the 'Discussion' section).

\section{Current land cover}

We used the $1 \mathrm{~km}$ resolution Global Land Cover 2000 (GLC2000) map [European Commission Joint Research Centre (EU JRC) 2003] to derive the fraction of each cell corresponding to the following three current land cover classes: (1) forested land (GLC2000 classes 1-6); (2) other natural lands (GLC2000 classes 7-15 and 50\% of the mixed classes 17 and 18), such as shrubland, herbaceous land and mangroves; and (3) cultivated or managed areas (GLC2000 classes 16 and $50 \%$ of classes 17 and 18), which include land converted for crop production and managed pasture (but not unmanaged pasture land, which is included under other natural land cover). GLC2000 land cover data have been produced and validated regionally and are generally considered more accurate and identify forest cover more accurately than alternatives (e.g. $81 \%$ accuracy for forest vs $60 \%$ accuracy for GlobCover 2005; Fritz et al. 2011), and for the purpose of this study were considered the best available data (Mayaux et al. 2006).

Biophysical suitability for agriculture

We obtained $5^{\prime} \times 5^{\prime}$ resolution data on land suitability for agriculture from the Global Agro-Ecological Zones (GAEZ; van Velthuizen et al. 2007). In their analysis, for each grid cell, suitability was assessed based on biophysical factors (including climate, soil and terrain conditions) for nine major crop groups (cereals, fibre crops, fibres, oil crops, pulses, roots and tubers, sugar crops, tree fruits and vegetables). The GAEZ methodology provides a suitability index (SI) for each grid cell for each crop under different input levels. We used SI data that assumes "maximised technological mix" for rain-fed agriculture (e.g. the higher level of technology and management inputs will be employed only in areas capable of producing high yields under those systems; for details how the SI was derived see van Velthuizen et al. 2007). Although biophysical factors do not 'drive' land-cover change directly, they influence land cover allocation decisions (e.g. according to slope or soil quality) (Verburg et al. 2004).

\section{Economic Pressure on Land index}

Our "Economic Pressure on Land" (EPL) index synthesizes distinct, but fundamentally synergistic demographic and economic forces related to land-cover change. Each grid cell is subject to an economic force for conversion that radiates from the nearest market in a direct relation to that market's demand and in an inverse relation to the travel distance between the grid cell and the market. Formally, the economic pressure of market centre $i\left(\mathrm{EP}_{\mathrm{i}}\right)$ is a function of its population $\left(P_{\mathrm{i}}\right)$ multiplied by the daily calorific intake of its population $\left(C_{\mathrm{i}}\right)$, plus the sum of the economic pressure of all other centres, each divided by the square-rooted distance (in kilometres) between centre $i$ and the respective "other" centre $j\left(d_{\mathrm{ij}}\right)$ :

$\mathrm{EP}_{\mathrm{i}}=\mathrm{P}_{\mathrm{i}} \mathrm{C}_{\mathrm{i}}+\sum_{j=1}^{n} \mathrm{P}_{\mathrm{j}} \frac{\mathrm{C}_{\mathrm{j}}}{\sqrt{d_{\mathrm{ij}}}}$

Each grid cell $k$ suffers an $\mathrm{EPL}_{\mathrm{k}}$ from conversion arising from the nearest centre, and in this step we incorporated travel costs arising from different land-cover and transport infrastructure. Travel costs, adapted from Nelson (2008), were 72 min per grid cell for natural land cover, 12 for tracks, 6 for rivers or sea, 4 for artificial surfaces, 3 for shipping lanes, 2 for major roads and $1 \mathrm{~min}$ for highways. The economic pressure on each grid cell $k$ is thus equal to the nearest centre's economic pressure $\left(\mathrm{EP}_{\mathrm{nc}}\right)$ divided by 
the square-rooted travel cost (in minutes) between them $\left(\mathrm{tc}_{\mathrm{knc}}\right)$ :

$\mathrm{EPL}_{\mathrm{k}}=\mathrm{EP}_{\mathrm{nc}} / \sqrt{\mathrm{tc}_{\mathrm{knc}}}$

Here, we defined market centres as cities with more than 50,000 people, yielding 8,518 centres [definition adopted from Nelson (2008)]. We then used a database of gridded world population for the year 2000 (CIESIN 2005) to assign the entire world's population to their nearest market centre (in kilometres). We multiplied the resulting combined urban and rural population by the average calorific intake of each market centre's country (Food and Agriculture Organisation 2006). In order to estimate the effect of trade between centres, we created a $8,518 \times 8,518$ matrix containing the distance between all market centres. For each cell, we effectively factored the pressure from all human individuals in the world, weighted by their consumption patterns and channelled by their respective market centres. The global economic pressure on land for the year 2000 is shown in Fig. 1.

In order to avoid distortion arising from using financial units in a global, long-term analysis, we used physical quantities for consumption (calorific intake), distance (kilometres) and travel cost (minutes per kilometre). Calorific intake is compatible with our observed variable (global land cover in 2000), as the latter relates to land converted to agriculture and cattle ranching, primarily food producing land uses (see also Goldewijk and Ramankutty
2004). Agriculture and cattle ranching comprise most of the historically converted land globally (Goldewijk and Ramankutty 2004) and our analysis does not include land converted to timber production or urban settlements.

\section{Protected areas}

When projecting the likelihood of land-cover change until 2050, we incorporated the effect of PAs into the analysis, by combining data from the World Database on Protected Areas (IUCN and UNEP 2009) and data from Joppa and Pfaff (2010) that estimate the effectiveness of PAs in each country. Spatial data for the area of all PAs declared under national legislation were selected from the World Database on Protected Areas (IUCN and UNEP 2009). For PAs without boundary data, but with information on latitude, longitude and an area, the PA's boundary was approximated by a circle of equivalent area centred on the latitude and longitude provided. Then, for each cell we multiplied the fraction classified as protected by the effectiveness of protection in each country, so that the "effectively protected area" (FPA) is equal to the protected area fraction multiplied by (1 - effectiveness of protection). This effectiveness of protection was obtained from Joppa and Pfaff (2010). Their study compared the proportion of natural land present within a representative sample of grid cells from PAs and within a matched sample of control sites from the rest of the country, for each country (Joppa and

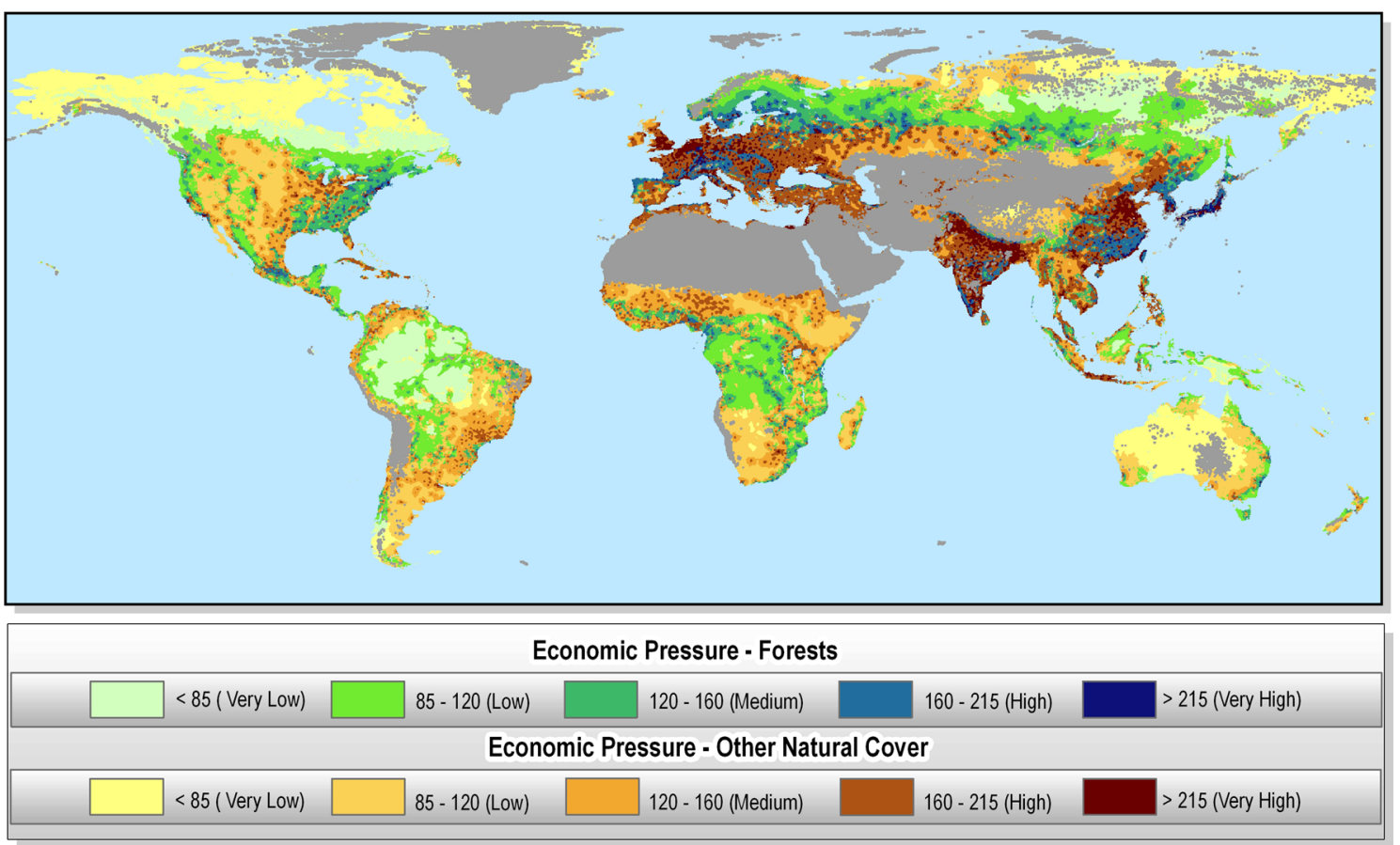

Fig. 1 Economic pressure for year 2000. Economic pressure on land index, resulting from population, consumption and distance to markets patterns. Different colour scales are applied for forests and non-forest areas. Deserts are shaded grey 
Pfaff 2010). The ratio of this proportion within and outside the protected area network (\% non-natural land in protected areas / \% non-natural land in control sites) was used as an estimate of effectiveness of the protected area network in preventing land-cover change. The simplistic assumptions were made that (a) all protected areas within a country were equally likely to resist land-cover change pressures and (b) all land within protected areas was in a natural state at the point of designation. No distinction was made between forested and non-forested PAs.

\section{Statistical analyses}

An ordinary least squares technique was used to explore the relationship between the extent of converted land, SI and EPL in 2000 on a grid-cell-by-grid-cell basis. A linear function was found to best explain the relationship between these variables, and hence to reflect the pattern of global land conversion (goodness of fit through $R^{2}$ and AIC analysis). We then estimated the projected extent of conversion of natural landscapes (both forests and other natural landscapes) for agricultural purposes by 2050. We used population projections (Goldewijk 2001) and calorific intake projections (Food and Agriculture Organization 2006) for 2050. The expected conversion was calculated as the difference between the projected extent of converted areas in 2050 (from the linear model) and the current conversion extent. The result was multiplied by the effectively protected fraction. In the regression, all variables were square root-transformed in order to normalise residuals. For each regression, the variance inflation factor (VIF, an indicator of multicollinearity) was verified. In all analyses we found VIF $<2$, indicating no multicollinearity. During method development we also tested the explanatory power of other factors that could potentially contribute to the analysis, such as GDP per capita or effect of PAs (see "Results"). We also applied various functions, such as linear or exponential, to test how the distance to markets affects the overall regression results.

During the selection of explanatory variables, we focussed on driving forces influencing land cover that are relevant for a global-scale analysis. For example, although specific policies may play a dominant role in land cover locally, it could be misleading or impractical to apply such policies globally and within a long-term analysis as applied here (for more details on driving forces behind land cover and scaling, refer to, for example, Verburg et al. 2004). To produce the final map of likelihood of further land-cover change we applied logistic regression (binary) including SI and EPL as explanatory variables and we assess the likelihood of conversion of at least an additional $10 \%$ of the land in the cell for agricultural purposes by 2050. Ten percent was selected as a conservative approach and this analysis can be rerun with alternative thresholds. We coded the converted area variable (originally 0-100\%) into binary (zero, one) variables, where zero equals no conversion and one is attributed to a converted grid cell. We then ran a set of binary regressions with different threshold values for considering a grid cell converted, at $1 \%$ of conversion extents intervals (e.g. 0-1\% of conversion equals zero and $1-100 \%$ equals one; $0-2 \%$ equals zero and 2-100\% equals one; etc.). This procedure was performed in order to establish the probability of conversion, depending on the current converted fraction of the grid cell. Then, for each grid cell, the binary coding chosen was equivalent to the conversion extent in the year 2000 plus $10 \%$ of conversion. In other words, if a cell converted fraction in the year 2000 was $27 \%$, the binary coding chosen for that cell was $0-36 \%$ equals zero and $37-100 \%$ equals 1 . The corresponding 'resulting likelihood' was equivalent to the likelihood of that grid cell undergoing $10 \%$ additional conversion. To calculate the 'final likelihood' of future land conversion, we included the effect of PAs (Eq. 3).

$\mathrm{FL}=\mathrm{RL}(1-\mathrm{FPA})$

where FL is the 'final likelihood', RL is the 'resulting likelihood' from binary regression and FPA the fraction of the grid cell effectively protected by PAs. Throughout the manuscript $R^{2}$ refers to 'adjusted $R^{2 \prime}$.

Case study: land-cover change emissions and REDD+

We combined the IPCC Tier-1 global biomass carbon map (for the year 2000) from Ruesch and Gibbs (2008) with the International Geosphere-Biosphere Programme map of soil carbon (IGBP-DIS 2000). The biomass data includes carbon stored in above- and below-ground living plant biomass. The soil carbon data estimates organic soil carbon to $1 \mathrm{~m}$ depth, which is appropriate for estimating soil carbon emissions from land conversions in most cases, but might underestimate carbon emissions from deeper peatland systems. We assumed that $100 \%$ of carbon stored in above- and below-ground biomass and $25 \%$ of the carbon stored in the soil would be emitted in the event of deforestation (volatile carbon). Current literature shows there is uncertainty over, and variability in, the proportion of soil carbon that is likely released during land-cover changes. Estimates of the proportion of soil carbon emitted in the event of deforestation range from $25 \%$ (Guo and Gifford 2002; Busch et al. 2009) to $40 \%$ (Kindermann et al. 2008). We did not account for any carbon removals or additions associated with subsequent agricultural cover.

It has been estimated that approximately 12 million ha have been deforested per year in the period 1990-2005, mostly in developing countries (Food and Agriculture Organisation 2006). Therefore, deforestation of 12 million 


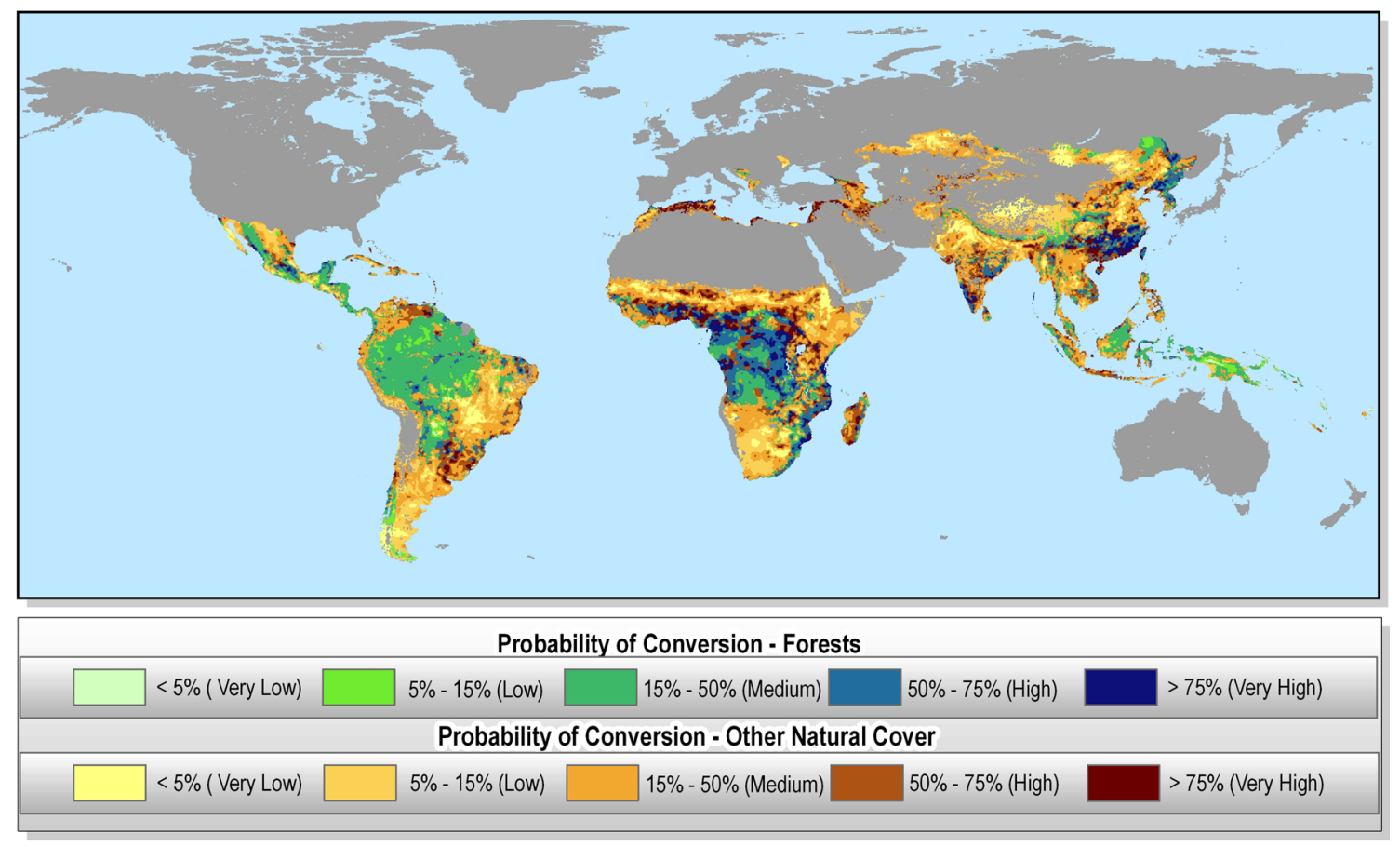

Fig. 2 Likelihood of land-cover change until 2050. Likelihood that a cell will experience at least $10 \%$ of further conversion by the year 2050. Different colour scales are applied for forests and non-forest areas. Deserts and Annex-I countries (not developing countries) are shaded grey

ha was adopted in this study as a "business as usual" (BAU) scenario for annual deforestation through 2050. These estimates do not include land-cover change outside forests, or reforestation and afforestation. To reflect the uncertainties involved, and given that our analysis covers conversion of any natural landscape, not just forested land, we also ran two alternative BAU scenarios, with $50 \%$ more (i.e. 18 million ha per year-"high BAU") and $50 \%$ less (6 million ha per year-"low BAU") annual deforestation. Our scenarios assume deforestation would occur in Latin America (including the Caribbean), sub-Saharan Africa and South, East and South East Asia (including countries from Oceania).

The geographic distribution of agricultural expansion was estimated using our likelihood of conversion map (Fig. 2), on the assumption that those areas characterised by the highest likelihood of conversion are being converted first. Once a grid cell was selected to be converted, the fraction of the grid cell converted within the BAU scenario corresponded to the predicted conversion (fraction of grid cell) for the year 2050. In the High BAU scenario, the amount converted per grid cell was increased by $50 \%$ in relation to the BAU scenario.

Lastly, we ran two further scenarios that incorporate the implementation of the REDD element of a REDD + scheme. The first scenario assumed that REDD is $100 \%$ effective (no further conversion in forested grid cells), the second that REDD is $50 \%$ effective (conversion in forested grid cells is $50 \%$ of that grid cell's BAU conversion). Using these scenarios, we investigated land-cover change-associated emissions in non-forest lands, if no other measures to decrease land demand are implemented.

\section{Results}

Selection of explanatory variables

During the selection of explanatory variables by the model describing land cover, GDP per capita as a proxy for consumption patterns was found to have a worse fit than calorific intake per capita (selected by the model). PA status was also found not to be significant $(P>0.05)$. Many PAs, mainly in developed countries, were established after land conversion, therefore their effect on long-term land-cover until 2000 as described by regression, was likely not significant. We further tested the explanatory power of constituents of the EPL. We found that, when calorific intake is combined with the distance to markets in the synthesised form of our index, its power to explain the global relationship of converted areas increased, compared with the regression that incorporated these values separately $\left(R^{2}=0.33\right.$ vs $\left.R^{2}=0.27\right)$.

Regression and the likelihood of future land-cover change in developing countries

A linear effect of SI and EPL was found to best explain converted areas, hence to reflect the pattern of global land- 
Table 1 Results of ordinary least squares regression for 2000

\begin{tabular}{llllllll}
\hline & Global & Developed & Developing & Europe & Asia & Latin America & Africa \\
\hline Biophysical suitability coefficient & 0.35 & 0.45 & 0.33 & 0.50 & 0.59 & 0.23 & 0.23 \\
Economic pressure on Land coefficient & 0.47 & 0.31 & 0.58 & 0.36 & 0.36 & 0.87 & 0.5 \\
Adjusted $R^{2}$ & 0.45 & 0.54 & 0.35 & 0.64 & 0.52 & 0.24 & 0.21 \\
\hline
\end{tabular}

All coefficients $P<0.001$

Table 2 Percentage of land in different conversion likelihood categories

\begin{tabular}{|c|c|c|c|c|c|c|c|}
\hline Region & Biome & $\begin{array}{l}\text { Total area } \\
\text { (million ha) }\end{array}$ & $\begin{array}{l}\text { Very low } \\
(\%)\end{array}$ & $\begin{array}{l}\text { Low } \\
(\%)\end{array}$ & $\begin{array}{l}\text { Medium } \\
(\%)\end{array}$ & $\begin{array}{l}\text { High } \\
(\%)\end{array}$ & $\begin{array}{l}\text { Very high } \\
(\%)\end{array}$ \\
\hline \multirow[t]{2}{*}{ Africa and Near East } & Forests & 658 & 0 & 2 & 23 & 41 & 33 \\
\hline & Other natural lands & 2,651 & 4 & 35 & 36 & 14 & 10 \\
\hline \multirow[t]{2}{*}{ Latin America and Caribbean } & Forests & 867 & 1 & 5 & 61 & 27 & 5 \\
\hline & Other natural lands & 841 & 5 & 27 & 40 & 18 & 7 \\
\hline \multirow[t]{2}{*}{ Asia and Oceania } & Forests & 437 & 0 & 6 & 34 & 27 & 27 \\
\hline & Other natural lands & 1,360 & 2 & 25 & 44 & 14 & 12 \\
\hline
\end{tabular}

Very low likelihood corresponds to a likelihood of land conversion less than 5\%, low likelihood corresponds to 5-15\%, medium 15-15\%, whereas high and very high corresponds to likelihood of land-cover change of 50-75 and 75-100\%, respectively

Table 3 Percentage of carbon emitted at land conversion, by conversion likelihood categories (see Table 2)

\begin{tabular}{|c|c|c|c|c|c|c|c|}
\hline Region & Biome & $\begin{array}{l}\text { Total stock } \\
\text { (tera g C) }\end{array}$ & $\begin{array}{l}\text { Very low } \\
(\%)\end{array}$ & $\begin{array}{l}\text { Low } \\
(\%)\end{array}$ & $\begin{array}{l}\text { Medium } \\
(\%)\end{array}$ & $\begin{array}{l}\text { High } \\
(\%)\end{array}$ & $\begin{array}{l}\text { Very high } \\
(\%)\end{array}$ \\
\hline \multirow[t]{2}{*}{ Africa and Near East } & Forests & 85,408 & 0 & 1 & 21 & 44 & 33 \\
\hline & Other natural lands & 94,595 & 2 & 21 & 34 & 23 & 19 \\
\hline \multirow[t]{2}{*}{ Latin America and Caribbean } & Forests & 148,495 & 1 & 3 & 63 & 27 & 4 \\
\hline & Other natural lands & 58,621 & 4 & 20 & 44 & 22 & 8 \\
\hline \multirow[t]{2}{*}{ Asia and Oceania } & Forests & 56,257 & 0 & 7 & 39 & 26 & 20 \\
\hline & Other natural lands & 69,419 & 1 & 14 & 40 & 21 & 19 \\
\hline
\end{tabular}

cover in the year 2000 (Table 1). For a global regression including all countries, independent variables explained almost half of the global land-cover $\left(R^{2}=0.45\right)$. The fit of the model increased to 0.54 for Annex I (developed) countries. European land conversion is best explained by the model $\left(R^{2}=0.64\right)$. Among developing countries, the highest fit was observed for Asia $\left(R^{2}=0.52\right)$, followed by Latin America $\left(R^{2}=0.24\right)$ and African countries $\left(R^{2}=0.21\right)$.

When assessing likelihood of land-cover change through 2050 we divided grid cells into 'very low' to 'very high' likelihood of conversion to agriculture (Fig. 2). We estimated that one-third of all natural land cover in developing countries has a 'high' or 'very high' likelihood (probability of $50 \%$ or higher) of additional conversion of at least $10 \%$ of the land area for agricultural purposes (Table 2). A further $40 \%$ of natural land cover is characterised by 'medium' likelihood (probability between 15 and $50 \%$ ).
The greatest area of 'very high' likelihood of conversion was found in sub-Saharan Africa together with the greatest carbon stocks in forests and other natural land cover at very high likelihood of conversion (Tables 2, 3). Regarding forested land, sub-Saharan Africa has twice the area at highest probability compared with Latin America and South, East and South East Asia. This represents threequarters of its forested area, compared to one-third of Latin America's (larger) forest area and $62 \%$ of South, East and South East Asia's (smaller) forest area. This is because of the combination of higher suitability index, medium to high future EPL and low PAs effectiveness in sub-Saharan Africa. Indeed, Latin America has high SI but relatively lower EPL and more effective PAs, while forests in South, East and South East Asia come under high EPL, but have lower SI. Figure 3 illustrates the process, overlapping our variables (SI, EPL and FPA) to combine into a single map of likelihood of conversion. 


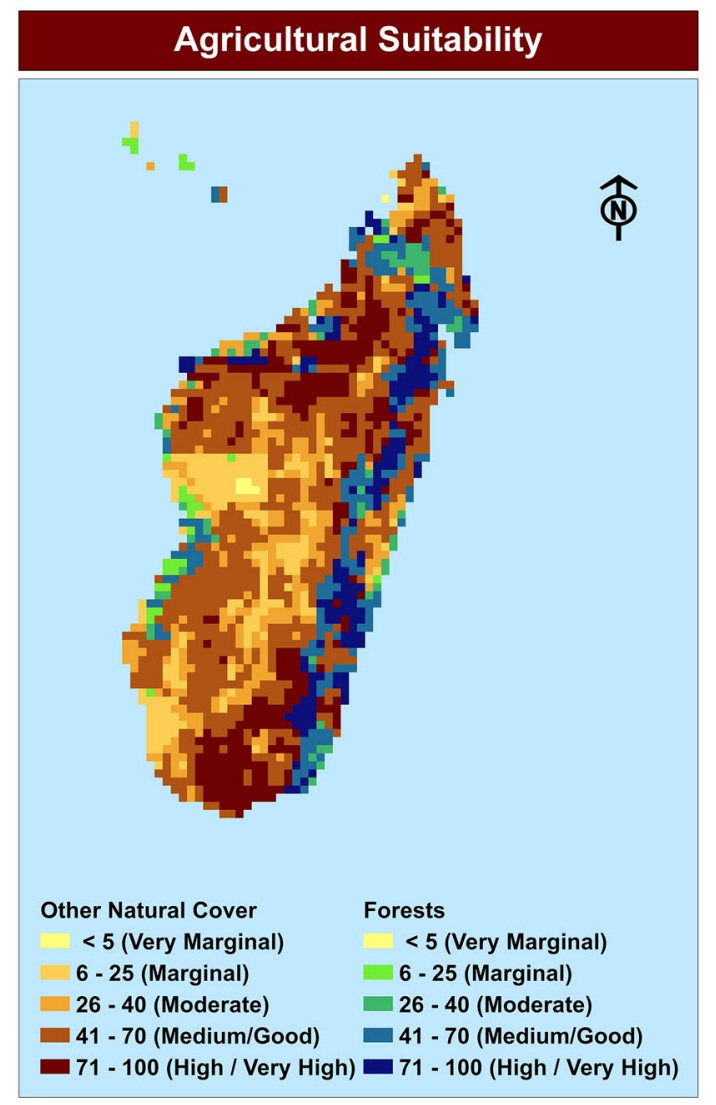

Economic Pressure (Year 2050)
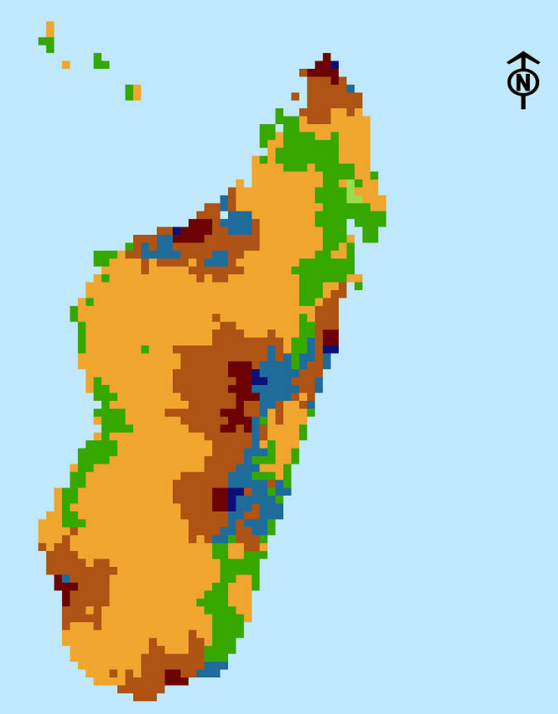

\begin{tabular}{|c|c|}
\hline Other Natural Cover & Forests \\
\hline$<85$ (Very Low) & $<85$ (Very Low) \\
$86-120$ (Low) & $86-120$ (Low) \\
$121-160$ (Medium) & $121-160$ (Medium) \\
$161-215$ (High) & $161-215$ (High) \\
$>215$ (Very High) & $>215$ (Very High) \\
\hline
\end{tabular}

\section{Effectively Protected Areas}

\section{Likelihood of Conversion}
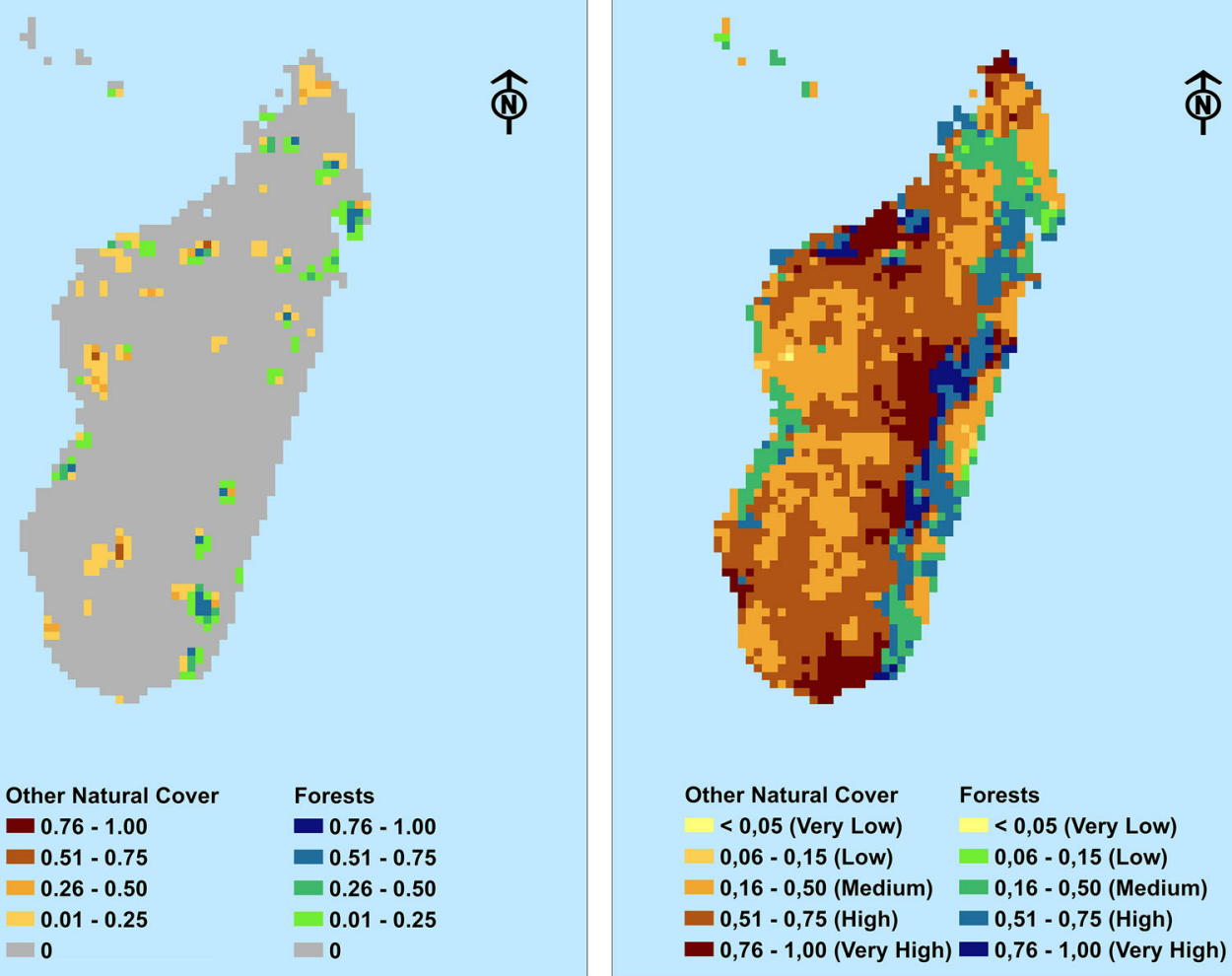
Fig. 3 Base layers and likelihood map for Madagascar showing detail on how the three base layers combine into a single map of likelihood of conversion. Agriculture suitability and economic pressure are indexes, whereas effectively protected areas and likelihood of conversion are fractions between 0 and 1

Scenario results for case study: land-cover change emissions and REDD+

In absolute terms, we estimated a relatively similar area of conversion in forest and other natural landscapes under BAU (Tables 4, 5). However, this represents a conversion rate of forested land three times higher than the conversion rate of other natural land cover. As expected, the relatively high carbon density of forests (particularly tropical forests) compared to other natural land cover, resulted in a greater emissions from forest conversion. For example, in the BAU scenario, deforestation caused $55 \%$ of converted areas and $70 \%$ of emissions. In the $100 \%$ effective REDD scenario without any further deforestation, the net mitigation impact of REDD resulted in a $30 \%$ reduction in BAU emissions from land-use change, as additional emissions from the additional conversion of other natural landscapes offsets $55 \%$ of the mitigated forest emissions. In the scenario where REDD reduces BAU deforestation by $50 \%$, the net mitigation impact is even smaller, at only $10 \%$.

\section{Discussion}

Our results suggest that biophysical suitability (as measured by SI) and a synthesised index of EPL can contribute to explaining long-term patterns in land cover. This is an accordance with others (Tilman et al. 2001, 2002; DeFries et al. 2010), who found a linear relationship between economic variables and converted areas. DeFries et al. (2010) showed that forest loss was correlated positively with economic indicators such as urban population growth and net agricultural trade per capita for the period 2000-2005 in 41 countries across the humid tropics $\left(R^{2}=0.47\right)$. In our model, biophysical suitability and EPL account for almost half of the global land-cover pattern in the year 2000, at a relatively high spatial resolution. Our results also demonstrate that the synthesized EPL index, which was developed to account for synergies between population data, demand and access to markets, has a significant explanatory power by itself $\left(R^{2}=0.33\right.$; $P<0.05)$ and may aid understanding of global long-term land-cover patterns.

Moreover, SI and EPL explained historical land conversion to a greater extent in developed countries than in developing countries (Table 1). This is not an unexpected result given that historical conversion of natural land into managed systems has most likely reached a long-term equilibrium in developed countries (and, possibly, refers to areas with low available forest), whereas land-cover conversion is an ongoing process in many developing countries with currently high deforestation rates in most of them (Food and Agriculture Organization 2006). In this sense, the model is very well aligned with the forest transition curve theory (Mather 1990). The best fit of the model observed for Europe, where land conversion driven by

Table 4 Reducing emissions from deforestation and forest degradation (REDD) scenario results for biome areas. BAU Business as usual

\begin{tabular}{|c|c|c|c|c|c|}
\hline Region & Biome & $\begin{array}{l}\text { Total area } \\
\text { (million ha) }\end{array}$ & $\begin{array}{l}\text { BAU scenario } \\
\text { (million ha) }\end{array}$ & $\begin{array}{l}\text { REDD } 100 \% \\
\text { (million ha) }\end{array}$ & $\begin{array}{l}\text { REDD } 50 \% \\
\text { (million ha) }\end{array}$ \\
\hline \multirow[t]{2}{*}{ Africa and Near East } & Forests & 658 & 163 & - & 113 \\
\hline & Other natural lands & 2,651 & 149 & 332 & 204 \\
\hline \multirow[t]{2}{*}{ Latin America and Caribbean } & Forests & 867 & 120 & - & 83 \\
\hline & Other natural lands & 841 & 67 & 151 & 92 \\
\hline \multirow[t]{2}{*}{ Asia and Oceania } & Forests & 437 & 40 & - & 28 \\
\hline & Other natural lands & 1,360 & 61 & 117 & 80 \\
\hline
\end{tabular}

Table 5 REDD scenario results for carbon stocks

\begin{tabular}{|c|c|c|c|c|c|}
\hline Region & Biome & $\begin{array}{l}\text { Total stock } \\
\text { (tera g C) }\end{array}$ & $\begin{array}{l}\text { BAU scenario } \\
\text { (tera g C) }\end{array}$ & $\begin{array}{l}\text { REDD } 100 \% \\
\text { (tera g C) }\end{array}$ & $\begin{array}{l}\text { REDD } 50 \% \\
\text { (tera g C) }\end{array}$ \\
\hline \multirow[t]{2}{*}{ Africa and Near East } & Forests & 85,408 & 21,440 & - & 14,839 \\
\hline & Other natural lands & 94,595 & 11,116 & 24,609 & 15,279 \\
\hline \multirow[t]{2}{*}{ Latin America and Caribbean } & Forests & 148,495 & 21,047 & - & 14,620 \\
\hline & Other natural lands & 58,621 & 5,203 & 11,780 & 7,163 \\
\hline \multirow[t]{2}{*}{ Asia and Oceania } & Forests & 56,257 & 5,953 & - & 4,103 \\
\hline & Other natural lands & 69,419 & 6,232 & 12,614 & 8,309 \\
\hline
\end{tabular}


agricultural expansion has been happening for longer (Goldewijk and Ramankutty 2004), further supports this interpretation. A similar trend is evident among developing countries. Considerably better fit for Asia, where the conversion process has been going on for longer than the more recent land conversion in Africa and Latin America, suggests the model is aligned with long-term patterns of land cover.

Our results also suggest (Fig. 2) that past trajectories of land conversion may not be appropriate to anticipate future trends. Indeed, although over recent centuries land conversion has been concentrated in developed countries, the ongoing process of conversion is now more focussed in developing countries, particularly in South-East Asia and Latin America. Importantly, even though Africa has been affected by land conversion to a lesser extent until now than, for instance Latin America, our projections add to a growing number of studies (UNEP 2007; Lambin and Meyfroidt 2011; World Bank 2011) suggesting that this situation will likely change in future decades. In addition to increased national demand for land due to increased population and consumption patterns, cross-border large-scale land acquisitions have recently taken place in capital-rich but food-poor countries (often oil-rich and water poor countries), such as Mozambique, Demographic Republic of Congo or Zambia. These transactions, sometimes referred to as 'the rush for Africa's land' or a 'land grab', are receiving increased attention from researchers, institutions and the media (Lambin and Meyfroidt 2011; World Bank 2011).

Our results further show that implementation of a narrowly focussed REDD + mechanism could result in unintended perverse land-cover change and carbon leakage. Similarly, potentially harmful side effects for some biodiversity areas have been reported (Miles and Kapos 2008; Strassburg et al. 2010). Our REDD scenarios illustrate a critical argument for the ongoing discussion within the UNFCCC: if REDD + does not include, or is not complemented by, initiatives to reduce the need for conversion of additional natural ecosystems, the effectiveness of REDD + on climate change mitigation will be significantly compromised. Our results show that $96 \%$ of forested land in developing countries is characterised by a medium, high or very high likelihood of conversion, and many biodiversity hotspots in Latin America, Africa and Southeast Asia present likelihood of further conversion. Our BAU scenario also suggests that forests will have three times higher conversion rates than other ecosystems, therefore suggesting that forests are indeed the first priority for policies addressing land-use and land-cover change. However, our results also show that if no measures to reduce demand for land are implemented, the net mitigation impact of REDD (whether 100 or $50 \%$ effective) can be reduced significantly by emissions arising from land-use and land-cover change "forced" into non-forested land, or "cross-biome leakage". This might be a conservative estimate, as it ignores the likely greater land requirements given the lower agricultural yield potential of some of these alternative ecosystems. Similarly, Galford et al. (2010) investigated greenhouse gas emissions from alternative futures of deforestation and agricultural management in the southern Amazon and concluded a need for taking into account post-clearing emissions and a need for of an integrated assessment of land-cover changes. In agreement with others (e.g. Galford et al. 2010) we also highlight, however, that avoided deforestation remains an important strategy for minimising future greenhouse emissions and that REDD + mitigation impacts are substantial, particularly where land-cover change is avoided on tropical forest peatlands. Taking these findings into account can be fundamental to the ultimate success of any REDD or similar mechanism under the UNFCCC. The original concept of RED proposed only incentives to reduce deforestation. The broadening to cover reductions in forest degradation and the 'plus' elements of conservation of forest carbon stocks, sustainable forest management and enhancement of forest carbon stocks, mean that those developing countries that have yet to suffer significant deforestation, or that are beginning to reforest, can also participate (Strassburg et al. 2010, 2012; Busch et al. 2009). Our findings, concomitant with those of other researchers, emphasise the need for relevant land-cover change policies that are not based exclusively on past patterns, for instance, incentives for forest protection and creation of new PAs on lands without long history land conversion but with high likelihood of future large-scale conversions (such as most of Africa).

\section{Limitations}

Although our focus on conversion for food producing systems covers most of the converted land globally, it would be a useful refinement to include other alternative land-covers such as timber plantations and biofuels. Spatial autocorrelation might have influenced our results and ideally should be accounted for in the statistical analyses. Given the data and spatial resolution of approximately 562,000 grid cells, it was however not feasible to run spatial mixed models that would account for spatial autocorrelation. Importantly, our methodology includes measure of distance and its impact on each grid cell, which has been recognised as a means of controlling for autocorrelation (Verburg et al. 2006). We did not account for the possible impacts of climate change on biophysical suitability and population distribution (Intergovermental Panel on Climate Change 2007). This analysis did not investigate dynamic land-cover change over time, therefore forest re- 
growth trajectories and afforestation, among other forest and managed to unmanaged-land transitions were not take into consideration. Finally, this study illustrates the relative likelihood of additional land conversion, taking into account selected factors. The actual extent of agricultural expansion in absolute terms will depend on additional factors, including the potential for higher yields and increased cropping intensity, and the balance of food of different types, among other biophysical, institutional and political factors.

\section{Conclusions: towards a whole-landscape approach}

In the real world, the allocation of land use and consequent land cover follow complex patterns involving a large number of variables including, amongst others, property rights, subsidies, national policies, local laws and traditions, and market price fluctuations. These variables vary considerably across space and time. Their incorporation at a global scale is usually hindered by lack of data and, in long-term analyses, their behaviour may be subject to highly uncertain scenarios. Here, we opted to simulate a simpler world, where land conversion responds to a combination of suitability for agriculture, the size and distance of the demand for food and the effective legal protection of the land. The quantitative and spatially explicit results of this study may serve as a base layer within which those more intricate relations will play their role. Our results suggest, however, that this basic model explains a significant proportion of the global land cover, and provides insights about what may be expected over the coming decades. We also demonstrated that interventions for reducing deforestation without complementary policies addressing the agricultural drivers of forest loss and demand for land, may have limited effectiveness in climate change mitigation. If national REDD + policies are to be effective, they must be accompanied by complementary international measures, such as trade regulation beyond the borders of individual countries to avoid leakage. Scientific and policy approaches should therefore encompass both forests and other natural ecosystems, as well as agricultural land, along with the links among them. This perspective incorporates the interdependencies and synergies involved in land-cover change and adopt the whole-landscape approach (DeFries and Rosenzweig 2010).

If the global population stabilizes at about 9 billion people, the coming 50 years may be the final episode of rapid global agricultural expansion and land-cover change. During this period, fuelled by increasing economic and demographic pressure, agriculture and other human subsistence practices have the potential to have irreversible impacts on the environment. Despite this gloomy prognosis there is evidence from a few countries, such as Costa Rica and Bhutan, that appropriate policies may allow an increase in food production without conversion of all available land (Ewers et al. 2009; Lambin and Meyfroidt 2011; Rudel et al. 2009). Understanding land-cover change trajectories presents a unique opportunity to estimate the size of possible displacement of land-cover, and to test the effects of policies to limit this problem. In doing so, it may aid in focusing and prioritising conservation efforts, and facilitate environmental management and planning in the context of a continued pursuit of economic development.

Acknowledgments This study was supported by the Gordon and Betty Moore Foundation, The Planetary Skin Institute and the UNREDD Programme.

Open Access This article is distributed under the terms of the Creative Commons Attribution License which permits any use, distribution, and reproduction in any medium, provided the original author(s) and the source are credited.

\section{References}

Baillie JEM, Hilton-Taylor C, Stuart SN (2004) A Global Species Assessment IUCN. Gland, Switzerland

Bouwman AF, Kram T, Klein Goldewijk K (eds) 2006 Integrated modeling of global environmental change. An overview of IMAGE 2.4. Netherlands Environmental Assessment Agency (MNP), Bilthoven, The Netherlands

Busch J, Strassburg B, Cattaneo A, Lubowski R, Bruner A, Rice R, Creed A, Ashton R, Boltz F (2009) Comparing climate and cost impacts of reference levels for reducing emissions from deforestation. Environ Res Lett 4:044006

Center for International Earth Science Information Network (CIESIN) (2005) Columbia University; and Centro Internacional de Agricultura Tropical (CIAT). Gridded Population of the World Version 3 (GPWv3). Palisades: Socioeconomic Data and Applications Center (SEDAC), Columbia University. http://sedac.ciesin. columbia.edu/gpw

Chomitz KM, Thomas TS (2003) Determinants of land-use in Amazonia: a fine-scale spatial analysis. Am J Agric Econ 85:1016-1028

DeFries R, Rosenzweig C (2010) Toward a whole-landscape approach for sustainable land use in the tropics. Proc Natl Acad Sci USA 107(46):19627-19632

DeFries RS, Rudel T, Uriarte M, Hansen M (2010) Deforestation driven by urban population growth and agricultural trade in the twentyfirst century. Nat Geosci 3:178-181. doi:10.1038/NGEO756

European Commission Joint Research Centre (EU JRC) (2003) Global Land Cover 2000 database. http://bioval.jrc.ec.europa.eu/ products/glc2000/glc2000.php

Evans TP, Manire A, de Castro F, Brondizio E, McCracken S (2001) A dynamic model of household decision-making and parcel level landcover change in the eastern Amazon. Ecol Model 143:95-113

Ewers RM (2006) Interaction effects between economic development and forest cover determine deforestation rates. Glob Environ Change 16:161-169

Ewers RM, Scharlemann JPW, Balmford A, Green RE (2009) Do increases in agricultural yield spare land for nature? Glob Change Biol 15:1716-1726 
Foley JA, DeFries R, Asner GP, Barford C, Bonan G, Carpenter SR, Chapin FS, Coe MT, Daily GC, Gibbs HK, Helkowski JH, Holloway T, Howard EA, Kucharik CJ, Monfreda C, Patz JA, Prentice IC, Ramankutty N, Snyder PK (2005) Global consequences of land-use. Science 309:570-574

Foley JA, Ramankutty N, Brauman KA, Cassidy ES, Gerber JS, Johnston M, Mueller ND, O'Connell C, Ray DK, West PC, Balzer C, Bennett EM, Carpenter SR, Hill J, Monfreda C, Polasky S, Rockstrom J, Sheehan J, Siebert S, Tilman D, Zaks DPM (2011) Solutions for a cultivated planet. Nature 478:337-342

Food and Agriculture Organization (2006) World agriculture: towards 2030/2050. Interim report. FAO, Rome

Fritz S, See L, McCallum I, Schill C, Obersteiner M, van der Velde M, Boettcher H, Havlík P, Achard F (2011) Highlighting continued uncertainty in global land cover maps for the user community. Environ Res Lett 6:044005

Galford GL, Melillo JM, Kicklighter DW, Cronin TW, Cerri CEP, Mustard JF, Cerri C (2010) Greenhouse gas emissions from alternative futures of deforestation and agricultural management in the southern Amazon. Proc Natl Acad Sci USA 107(46):19649-19654

Gibbs HK, Ruesch AS, Achard MK, Clayton MK, Holmgren P, Ramankutty N, Foley A (2010) Tropical forests were the primary sources of new agricultural land in the 1980s and 1990s. Proc Natl Acad Sci USA 107(38):16732-16737

Goldewijk KK (2001) Estimating global land use change over the past 300 years: the HYDE database. Glob Biogeochem Cycles 15(2):417-434

Goldewijk KK, Ramankutty N (2004) Land cover change over the last three centuries due to human activities: the availability of new global data sets. GeoJournal 61:335-344

Goldstein NC, Candau JT, Clarke KC (2004) Approaches to simulating the "March of Bricks and Mortar". Comput Environ Urban Syst 28:125-147

Guo LB, Gifford RM (2002) Soil carbon stocks and land usechange: a meta analysis. Glob Change Biol 8:345-360

Hsin H, van Tongeren F, Dewbre J, van Meij H (2004) A new representation of agricultural production technology in GTAP. GTAP resource No. 1504. http://www.gtap.agecon.purdue.edu

IGBP-DIS (2000) Global Soil Data Products CD-ROM. Global Soil Data Task, International Geosphere-Biosphere Programme, Data and Information System, Potsdam, Germany

Intergovermental Panel on Climate Change (2007). Climate change. Synthesis report, Valencia, Spain

International Union for Conservation of Nature, United Nations Environment Programme (2009) The world database on protected areas (WDPA). UNEP-WCMC, Cambridge

IUCN Red List of Threatened Species. Version 2011.1. http://www.iucnredlist.org. Downloaded 22 October 2011

Joppa LN, Pfaff A (2010) Re-assessing the forest impacts of protection: the challenge of non-random location and a corrective method. Annu Rev Ecol Econ 1185:135-149

Kindermann G, Obersteiner M, Sohngen B, Sathaye J, Andrasko K, Rametsteiner E, Schlamadinger B, Wunder S, Beach R (2008) Global cost estimates of reducing carbon emissions through avoided deforestation. Proc Natl Acad Sci USA 105:10302-10307

Lambin EF, Meyfroidt P (2011) Global land use change, economic globalization, and the looming land scarcity. Proc Natl Acad Sci USA 108(9):3465-3472

Lambin EF, Rounsevell MDA, Geist HJ (2000) Are agricultural landuse models able to predict changes in land-use intensity? Agric Ecosyst Environ 82:321-331

Lepers E, Lambin EF, Janetos AC, DeFries R, Achard F, Ramankutty N, Scholes RJ (2005) A synthesis of information on rapid landcover change for the period 1981-2000. Bioscience 55:115-124
Mather A (1990) Global forest resources. Bellhaven, London

Mayaux P, Eva H, Gallego J, Strahler AH, Herold M, Agrawal S, Naumov S, De Miranda EE, Di Bella CM, Ordoyne C, Kopin Y, Roy SP (2000) IEEE Trans Geosci Remote Sens 44(7), JULY 2006 Validation of the Global Land Cover 2000 Map

Meyfroidt P, Rudel TK, Lambin E (2010) Forest transitions, trade, and the global displacement of land use. Proc Natl Acad Sci USA 107: 20917-20922

Miles L, Kapos V (2008) Reducing greenhouse gas emissions from deforestation and forest degradation: global land-use implications. Science 320:1454-1455

Nelson A (2008) Travel time to major cities: a global map of accessibility. Global Environment Monitoring Unit-Joint Research Centre of the European Commission, Ispra Italy. http://gem.jrc.ec.europa.eu/

Overmars KP, Verburg PH (2005) Analysis of land-use drivers at the watershed and household level: linking two paradigms at the Philippine forest fringe. Int J Geograph Inf Sci 19:125-152

Pontius RG, Cornell JD, Hall CAS (2001) Modeling the spatial pattern of land-use change with GEOMOD2: application and validation for Costa Rica. Agric Ecosyst Environ 85:191-203

Ramankutty N, Gibbs HK, Achard F, Defries R, Foley JA, Houghton RA (2007) Challenges to estimating carbon emissions from tropical deforestation. Glob Change Biol 13:51-66

Reid R, Gichohi H, Said M, Nkedianye D, Ogutu J, Kshatriya M, Kristjanson P, Kifugo S, Agatsiva J, Adanje S, Bagine R (2008) Fragmentation of a Peri-Urban Savanna, Athi-Kaputiei Plains, Kenya. In: Galvin KA,Reid RS,Behnke RH Jr, Thompson Hobbs $\mathrm{N}$ (eds) Fragmentation in semi-arid and arid landscapes. Springer, Dordrecht, pp 195-224

Rindfuss RR, Walsh SJ, Turner BL, Fox J, Mishra V (2004) Developing a science of land change: challenges and methodological issues. Proc Natl Acad Sci USA 101:13976-13981

Rosegrant MW, Meijer S, Cline SA (2002) International model for policy analysis of agricultural commodities and trade (IMPACT): model description. International Food Policy Research Institute, Washington, DC

Rudel TK, Coomes OT, Moran E, Achard F, Angelsen A, Xu JC, Lambin E (2005) Forest transitions: towards a global understanding of landuse change. Glob Environ Change Hum Policy Dimens 15:23-31

Rudel TK, Schneider L, Uriarte M, Turner BL II, DeFries R, Lawrence D, Geoghegan J, Hecht S, Ickowitz A, Lambin EF, Birkenholtz T, Baptista S, Grau R (2009) Agricultural intensification and changes in cultivated areas, 1970-2005. Proc Natl Acad Sci USA 106:20675-20680

Ruesch AS, Gibbs HK (2008) New IPCC Tier-1 global biomass carbon map for the year 2000 Carbon Dioxide Information Analysis Center. Oak Ridge National Laboratory, Oak Ridge

Smith P, Gregory PJ, van Vuuren D, Obersteiner M, Havlik P, Rounsevell M, Woods J, Stehfest E, Bellarby J (2010) Competition for land. Philos Trans R Soc B 365:2941-2957

Soares BS, Nepstad DC, Curran LM, Cerqueira GC, Garcia RA, Ramos CA, Voll E, McDonald A, Lefebvre P, Schlesinger P (2006) Modelling conservation in the Amazon basin. Nature 440:520-523

Stephenne N, Lambin EF (2001) A dynamic simulation model of land-use changes in Sudano-sahelian countries of Africa (SALU). Agric Ecosyst Environ 85:145-161

Strassburg B, Turner RK, Fisher B, Schaeffer R, Lovett A (2009) Reducing emissions from deforestation: the "combined incentives" mechanism and empirical simulations. Glob Environ Change 19(2):265-278. doi:10.1016/.j.gloenvcha.2008.11.004

Strassburg BBN, Kelly A, Balmford A, Davies RG, Gibbs HK, Lovett A, Miles L, Orme CDL, Price J, Turner RK, Rodrigues ASL (2010) Global congruence of carbon storage and biodiversity in terrestrial ecosystems. Conserv Lett 3:98-105 
Strassburg BBN, Rodrigues ASL, Gusti M, Balmford A, Fritz S, Obersteiner M, Turner RK, Brooks TM (2012) Impacts of incentives to reduce emissions from deforestation on global species extinctions. Nat Clim Change 2:350-355. doi: 10.1038/nclimate1375

Tilman D, Fargione J, Wolff B, D'Antonio C, Dobson A, Howarth R, Schindler D, Schlesinger WH, Simberloff D, Swackhamer D (2001) Forecasting agriculturally driven global environmental change. Science 292:281-284

Tilman D, Cassman KG, Matson PA, Naylor R, Polasky S (2002) Agricultural sustainability and intensive production practices. Nature 418:671-677

Trimble SW, Crosson P (2000) Land-use-US soil erosion ratesmyth and reality. Science 289:248-250

Turner M (2010) A landscape perspective on sustainability science. In: Levin SA, Clark WC (eds) Toward a science of sustainability. University Services, Princeton University, Princeton, NJ, pp 79-82

UNFCCC (2010) Cancun Agreements. http://cancun.unfccc.int/

van Ittersum MK, Roetter RP, van Keulen H, de Ridder N, Hoanh CT, Laborte AG, Aggarwal PK, Ismail AB, Tawang A (2004) A systems network (SysNet) approach for interactively evaluating strategic land-use options at sub-national scale in South and South-east Asia. Land Use Policy 21:101-113

van Velthuizen H, Huddleston B, Fischer G, Salvatore M, Ataman E, Nachtergaele FO, Zanetti M, Bloise M (2007) Mapping biophysical factors that influence agricultural production and rural vulnerability. Environ Nat Res Ser No. 11, FAO, Rome

Verburg PH, Soepboer W, Veldkamp A, Limpiada R, Espaldon V, Mastura SSA (2002) Modeling the spatial dynamics of regional land-use: the CLUE-S model. Environ Manag 30:391-405

Verburg PH, Schot P, Dijst MJ, Veldkamp A (2004) Land use change modelling: current practice and research priorities. GeoJournal 61:309-324

Verburg PH, Kok K, Pontius Jr RG, Veldkamp A (2006) Modelling land-use and land-cover change. In: Lambin EF, Geist HJ (eds) Land-use and land-cover change. Local processes and global impacts. Springer, Berlin

Von Thunen JH (1826) The isolated state. [Hall P (ed) Von Thünen's Isolated State (English translation by Carla M. Wartenberg, with an introduction by the editor), Pergamon, London (1966)]

World Bank (2011). Rising global interest in farmland. In: Can it yield sustainable and equitable benefits? Washington, DC 